\title{
Fecundity and condition of Chrysichthysnigrodigitatus (Family Claroteidae) in Yewa Lagoon, Nigeria
}

Taiwo, I.O., Olopade, O.A. and Tiamiyu, A.I. Department of Renewable Resources Olabisi Onabanjo University, Yewa Campus, Ayetoro, Ogun State.

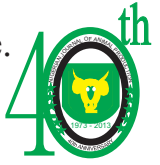

\begin{abstract}
The minimum and maximum standard length of females caught was $8.0 \mathrm{~cm}(14.5 \mathrm{~g}$ body weight) and $14.6 \mathrm{~cm}$ (53.4g body weight) respectively while the males were $10.1 \mathrm{~cm}(19.8 \mathrm{~g})$ and $17.1 \mathrm{~cm}(68.6 \mathrm{~g})$. The gonadosomatic index (GSI) for females ranged between 6.55 and 25.57 while males ranged between 5.68 and 16.55. Significant $(P<0.05)$ relationships were observed between standard length, body weight, gonad weight and fecundity. There was significant $(P<0.05)$ relationship between body weight and fecundity. Body weight and GSI had no significant $(P>0.05)$ relationship with condition factor in C. nigrodigitatus in Yewa Lagoon. The condition factor $(K)$ ranged between 1.58 and 2.92 for the females while males ranged between 1.08 and 2.79. The condition of female fish was slightly better than that of male fish of the same length.
\end{abstract}

Keywords: Fecundity, Chrysichthys nigrodigitatus

\section{Introduction}

Marked differences in the fecundity among species often reflect different reproduction strategies (Murua and Saborido-Rey, 2003). Within a given species, fecundity may vary as a result of different adaptation to environmental habitat (Withameet al., 1995). Even within a stock, fecundity is known to vary annually, undergo long-term changes (Horwoodet al., 1986; Rijnsdorp 1991; Kjesbuet al., 1998) and has been shown to be proportional to the fish size (and hence age) and condition. Larger fish produce more eggs, both in absolute and in relative terms in relation to body mass. For a given sizes, females in better condition exhibit higher fecundity (Kjesbuet.al., 1991). Studies on reproduction including the assessment of size at maturity, fecundity, duration of reproductive season, daily spawning behaviour and spawning fraction permits quantification of the reproductive capacity of individual fish (Saville, 1964; Parker, 1980; Lasker, 1985). This has led to a better understanding of observed fluctuations in reproductive output and enhanced the ability to estimate recruitment (Kraus et al., 2002). Fish sizes and condition are thus key parameters to properly assess fecundity at the population level.

Chrysichthysnigrodigitatus (Lacépède: 1803 ) is a highly valued food-fish included among the dominant commercial catches exploited in major rivers of Africa (Offemet al., 2008). Bagenal andTesch(1978) stated that condition factor is an index of the degree of fatness or well-being of a species. Thus, the study of the condition factor of fish species contributes to adequate management of the species and to keep the e cosystem at equilibrium (HarunaandBichi, 2005). Condition index may be used to determine the reproductive time of fish species without sacrificing the organismswhich could be a valuable tool to develop monitoring programs for the fishspecies (Arellano-Martinez andCeballos-Vazquez, 2001).Knowledge of fish fecundity will also help in predicting 
the level of fertilization of eggs and survival rate of hatchlings. It will also help the fish farmer to predict the level of fingerlings and adult fish production from time to time. This study was carried out to determine thecondition factor and the relationship between weight and fecundity of Chrysichthysnigrodigitatus and its condition in Yewa Lagoon.

\section{Materials and Methods}

$\mathrm{F} \mathrm{i} \mathrm{s} \mathrm{h} \mathrm{s} \mathrm{p} \mathrm{e} \mathrm{c} \mathrm{i} \mathrm{m} \mathrm{e} \mathrm{n} \mathrm{s}$ ofChrysichthysnigrodigitatus(300) were gotten live from fishermen at Yewa Lagoon, Ipokia Local Government, Ogun State during the rainy season (i.e.April -August). The specimens were caught with bamboo traps and preserved with crushed ice for transporting to the laboratory. A total of 300 specimens ofC. nigrodigitatuswere collected and used. The total and standard lengths of the specimens were measured to the nearest centimetres using a graduated measuring board. The body weight of the specimens were taken using a top loading weighing balance measured to the nearest grams.

The eggs were preserved using Gilson fluid $(60 \%$ alcohol, $880 \mathrm{ml}$ water, $15 \mathrm{ml}$ nitric acid, $18 \mathrm{ml}$ glacial acetic acid, $20 \mathrm{~g}$ mercury chloride). This made it easier to count the eggs because it liberated and broke down the ovarian tissue. Volumetric sub sampling method of estimating fecundity was usedfor counting the eggs (Fagade and Adebisi, 1979). The volume of a portion of the subsample is determined and the number of eggs in that volume is counted and this is extrapolated to the total volume of the original ovary from which the subsample was taken.

$$
\mathrm{a} / \mathrm{x} \times \mathrm{y}
$$

$$
\text { Fecundity estimation }=
$$

$\mathrm{x}=$ Volume of subsample ovary

$a=$ Number of eggs in" $x$ "

$y=$ Volume of ovary sample

The G.S.I of the fish was determined as weight of gonad/ body weight of fish $\times$ 100/1. The condition of the fish was calculated using Fulton coefficient formula; $\mathrm{K}^{\prime}=100 \mathrm{~W} / \mathrm{L}^{\mathrm{b}}$ (Bagenal\&Tesch, 1978); whereK' = condition factor, $\mathrm{W}=$ body weight $(\mathrm{g}), \mathrm{L}=$ standard length, and $\mathrm{b}$ regression (growth) coefficient. Regression analysis was used to determine the relationship between body weight, standard length and the gonado-somatic parameters of $C$. nigrodigitatus.

\section{Results}

More females were collected with a female:male ratio of 2:1 (Table 1). The body weight -standard length relationshipof $C$. nigrodigitatus showed that body weight proportionally increased as the standard length increased with a high $\mathrm{R}^{2}$ of more than 70 (Fig. 1). The larger (body weight)the fish, the higher the relative fecundity with an $\mathrm{R}^{2}=0.59$ (Fig. 2). Gonad weight -body weight relationship of female and male $C$. nigrodigitatusshowed that the gonad

Table 1: Sex ratio of Chrysichthysnigrodigitatusin Yewa Lagoon

\begin{tabular}{lccc}
\hline Month & Females & Males & Sex ratio (F:M) \\
\hline April & 33 & 28 & $0.5: 0.4$ \\
May & 40 & 20 & $0.6: 0.3$ \\
June & 38 & 17 & $0.7: 0.3$ \\
July & 40 & 8 & $0.8: 0.2$ \\
August & 34 & 22 & $0.6: 0.4$ \\
September & 15 & 5 & $0.7: 0.3$ \\
\hline Total & 200 & 100 & $2: 1$ \\
\hline
\end{tabular}



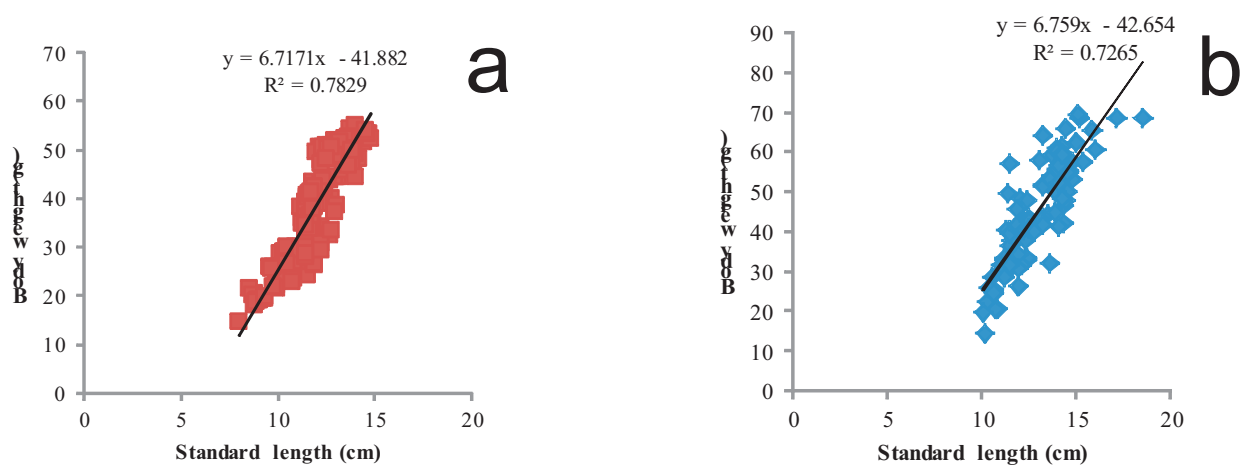

Fig. 1: Body weight-Standard length relationship in female (a) and male (b) C. nigrodigitatus

weight increased with the body weight, however, $\mathrm{R}^{2}=0.59$ (Fig. 3a) and 0.75 (Fig. $3 b)$ respectively. Gonad weight -standard length relationship of female and male $C$. nigrodigitatusshowed that the gonad weight increased with the body weight but not proportionately, $\mathrm{R}^{2}=0.48$ (Fig. $3 \mathrm{a}$ ) and 0.56 (Fig. 3b)respectively. The Body weight and GSI ofC. nigrodigitatus in Yewa Lagoon had no significant $(\mathrm{P}>0.05)$ relationship with condition factor.

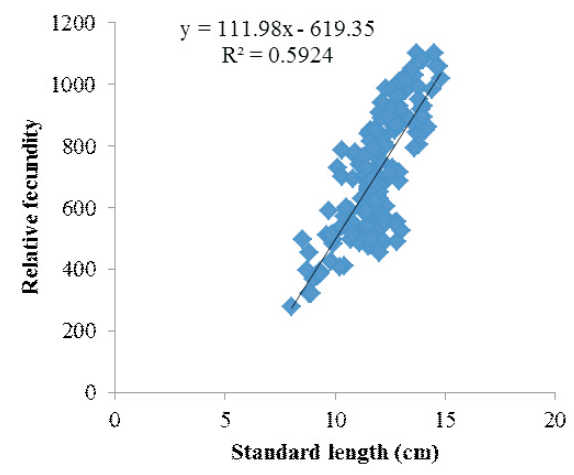

\section{Discussion}

The body weight - standard length relationship was highly significant with $\mathrm{R}^{2}$ values of more than $70 \%$ which showed that body weight and length increased proportionately. Offemet al. (2008) got similar results from another water body in Cross River State, Nigeria. Figures 3, 4 and 5 showed the significance of body weight with fecundity and gonad weight, indicating that the more the eggs and weight of the gonads the larger the fish. This study revealed that fecundity varied with body weight among fishes of the same body weight. This variation becomes more pronounced with increase in body size. Ayaosi (2002) obtained similar results from C. walkeri in Asejire Lake.

Females had a minimum and maximum standard length of $8.0 \mathrm{~cm}(14.5 \mathrm{~g}$ body weight) and $14.6 \mathrm{~cm}$ (53.4g body weight) respectively while the males were $10.1 \mathrm{~cm}$ $(19.8 \mathrm{~g})$ and $17.1 \mathrm{~cm}(68.6 \mathrm{~g})$. The sizes of fishes obtained were lower than that reported by Taiwo and Odunaiya (2004) and Taiwo and Olopade (2009). The Fig. 2: Fecundity - Body weight relationship in C. nigrodigitatus minimum standard length of matured 


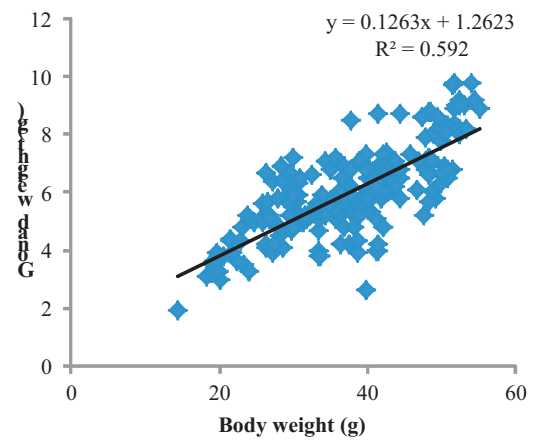

a

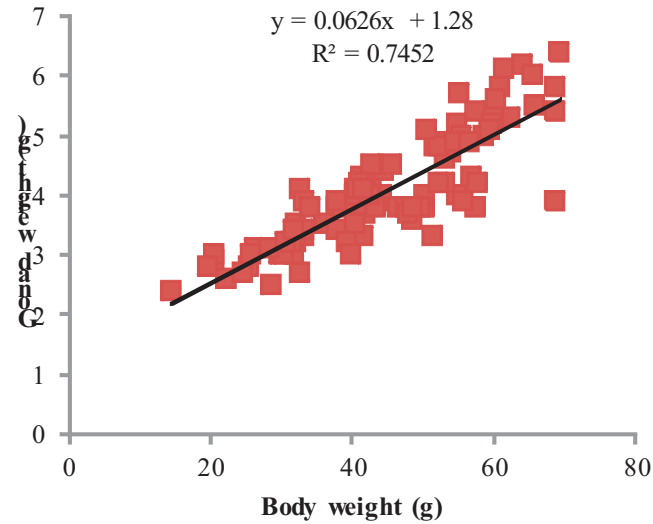

b

Fig. 3: Gonad weight-Body weight relationship in female (a) and male (b) C. nigrodigitatus
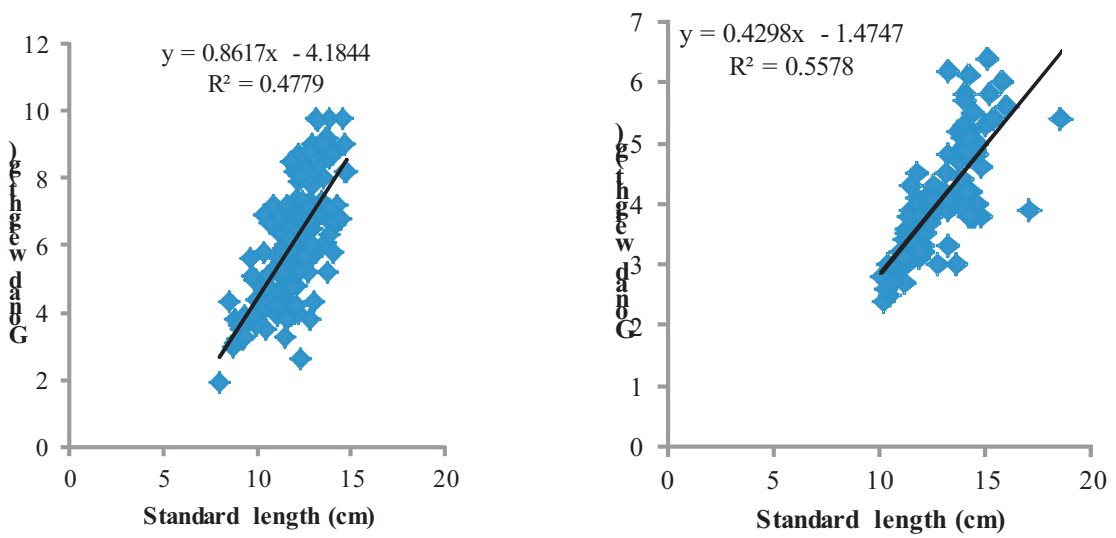

Fig. 4: Gonad weight - Standard length relationship in female (a) and male (b) $C$. nigrodigitatus 
female fish of $C$. nigrodigitatus was found to be $10.1 \mathrm{~cm}$ with body weight of $28.6 \mathrm{~g}$ and estimated fecundity of 730eggs while the maximum standard length recorded for the fecund fish was $13.7 \mathrm{~cm}$ with body weight of $54.4 \mathrm{~g}$ and estimated fecundity of 1100 eggs at gonad stage II. This fecundity is similar to that recorded for $C$. walker and $C$. nigroigitatusfrom Asejire Lake which was 124 eggs for a $20 \mathrm{~g}$ fish and 13,746 eggs for a fish weighing $475 \mathrm{~g}$ (Taiwo and Odunaiya, 2004 and Taiwo and Olopade, 2009). The gonadosomatic index for females ranged between 6.55 and 25.57 while males ranged between 5.68 and 16.55. Significant $(\mathrm{P}<0.05)$ relationships were observed between standard length, body weight and gonad weight. There was a strong significant $(\mathrm{P}<0.05)$ relationship between body weight and fecundity. The mean condition factor $(\mathrm{K})$ of 2.92 for the females was slightly higher than that of males of 2.79. This was in agreement with Offemet al. (2008) and Atobalele and Ugwumba (2011). AdedejiandAraoye (2006) also observed that female Synodontisschall were in slightly better condition than their male counterparts. The condition factor indicated that the females were slightly heavier than their male counterpart of the same length which could also be due to the weight of the gonads.

\section{Conclusion}

Size of fish in relation to length and body weight has an influence on the fecundity of $C$. nigrodigitatus. Hence the nutritional state and condition of the parent fish under culture are very important factors influencing the number of eggs produced. It can be inferred that more females are in abundance than males of $C$. nigrodigitatusin Yewa lagoon.

\section{References}

Atobalele, O.E and Ugwumba, A.O. 2011. Condition factor and diet of Chrysichthysnigrodigitatus and Chrysichthysauratus (Siluriformes: Bagridae) from Aiba Reservoir, Iwo, Nigeria. Rev. Biol Trop 59(3):1233-44.

Adedeji, R.A. \& P.A. Araoye. 2006. Study and characterization in the growth of body parts of Synodontisschall(Pisces: Mochokidea) from Asa Dam, Ilorin, Nigeria. Nigerian J. Fisheries 2/3: 219244.

Arellano-Martinez, M. and B.P. Ce b a l l os - Vazquez. 2001 Reproductive activity and condition index of Holocanthus passer (Teleostei: Pomacanthidae) in the Gulf of California, Mexico. Rev. Biol. Trop. 49: 939-943.

Bagenal, T.B. and F.W. Tesch. 1978 Age and growth, p. 101-136. In T.B. Bagenal (ed.). Methods for assessment of fish production in freshwaters. Blackwell, London, England

Fagade, S.O and Adebisi, A.A 1979. On $\mathrm{th}$ e f e c u n i t y of Chrysichthysnigrodigitatus of Asejire Dam, Oyo State Nigeria J. of Natural Resources 1(2): 127-131.

Haruna, M. and A.H. Bichi 2005. Studies on length-weight relationship and condition factor of the cichlids of Tomas Lake, Kano, Nigeria. Biol. Environ. Sci. J. Trop. 2: 94-100.

Horwood, J.W., R.C.A. Bannister and G.J. Hawlett 1986. Comparative fecundity of North Sea plaice (PleuronectesplatessaL.) Proc.R. Soc. Lond. B. 228: 401-431.

Kjesbu, O.S, J. Klungsoyr, H. Kryvi, P.R. Witthamesand W.M.Greer 1991. Fecundity, atresia and egg size of captive Atlantic cod (Gadusmorhua) in relation to proximate body 
composition. Can. J. Fish Aqua.Sc. 48: 2333-2343.

Kjesbu, O.S, Witthames, P.R, Solemdal P, and Greer, W.M 1998. Temporal variation in the fecundity of arctonorwegian cod (Gadusmorheia) in response to natural changes in food and temperatures. J. Sea Res. 40:303-332.

Kraus, G.S. Tomkiewic and Koster, F.W. 2002. egg production of Baltic cod in relation to variable sex ratio, maturity and security. Can. J. Fish Aqua.Sc. 59: 1908-1920.

Lasker R. 1985. An egg production method for estimating spawring biomass of pelagic fish.Application to the northern anchovy.Engranlismordex Us Dep comm. NOAA Tech, Rep.

Murua and Saborido. (2003. Available information for estimating reproductive potential of North West Atlantic ground fish stocks .1. North W. Atl. Fish.sci. 33: 23-31.

Offem, B.O, Akegbejo-Samsons and Omoniyi I.T 2008. Diet, size and reproductive biology of the silver catfish, Chrysichthysnigrodigitatus (Siluriformes: Bagridae) in the Cross River, Nigeria. Rev. Biol Trop 56(4):1785-99.
Parker K. 1980. A direct method for estimating Northern Anchovy, Eugranhsmordex, spawning biomass. Fish Bull U.S.

Rijnsdorp, A.D 1991. Changes in fecundity of female north sea plaice (Pleuronectesplatessa) between 3 period since 1900. ICES J. Mar. Sci. 48:253-280.

Saville, A. 1964. Estimation of the abundance of a fish stock from egg larvae surveys. ICES. Rapp. Proc. Verb. 55: 164-173.

Taiwo, I.O. and Odunaiya, O. 2004. Sex Ratio and Fecundity of Chrysichthysnigrodigitatus (Family Claroteidae) from Asejire Lake, Nigeria.Nig. J. of Anim. Prod. 31 (1): 135-143.

Taiwo, I.O. and Olopade, O.A. 2009. Some aspects of the Biology of Chrysichthyswalkerifrom Asejire Lake, Nigeria. Int. J. of Agric. and Apicultural Res. 5 (1 \& 2): 44-54

Witthames, P.R, Greer, M.W, Dinis. M.T and Whitng.G.L 1995. The geographical variation in the potential of annual fecundity of dover solesoleasolea, from European shelf waters. J. Sea Res. 34: 45-58.

Received: 20/02/12 Accepted: 10/06/13 